\title{
Variations in community exposure to lahar hazards from multiple volcanoes in Washington State (USA)
}

\author{
Angela K Diefenbach ${ }^{1 *}$, Nathan J Wood ${ }^{2}$ and John W Ewert ${ }^{1}$
}

\begin{abstract}
Understanding how communities are vulnerable to lahar hazards provides critical input for effective design and implementation of volcano hazard preparedness and mitigation strategies. Past vulnerability assessments have focused largely on hazards posed by a single volcano, even though communities and officials in many parts of the world must plan for and contend with hazards associated with multiple volcanoes. To better understand community vulnerability in regions with multiple volcanic threats, we characterize and compare variations in community exposure to lahar hazards associated with five active volcanoes in Washington State, USA-Mount Baker, Glacier Peak, Mount Rainier, Mount Adams and Mount St. Helens-each having the potential to generate catastrophic lahars that could strike communities tens of kilometers downstream. We use geospatial datasets that represent various population indicators (e.g., land cover, residents, employees, tourists) along with mapped lahar-hazard boundaries at each volcano to determine the distributions of populations within communities that occupy lahar-prone areas. We estimate that Washington lahar-hazard zones collectively contain 191,555 residents, 108,719 employees, 433 public venues that attract visitors, and 354 dependent-care facilities that house individuals that will need assistance to evacuate. We find that population exposure varies considerably across the State both in type (e.g., residential, tourist, employee) and distribution of people (e.g., urban to rural). We develop composite lahar-exposure indices to identify communities most at-risk and communities throughout the State who share common issues of vulnerability to lahar-hazards. We find that although lahars are a regional hazard that will impact communities in different ways there are commonalities in community exposure across multiple volcanoes. Results will aid emergency managers, local officials, and the public in educating at-risk populations and developing preparedness, mitigation, and recovery plans within and across communities.
\end{abstract}

Keywords: Lahar; Exposure; Risk; Volcano; Hazards; GIS; Vulnerability

\section{Introduction}

The catastrophic destruction associated with recent lahars (e.g., 1985 Nevado del Ruiz, Colombia; 1991 Mount Pinatubo, Philippines; 1998 Casita, Nicaragua) has raised global awareness of this ground-based volcanic hazard. Lahars, which are high-concentration mixtures containing water and solid particles of rock, ice, wood, and other debris, are significant volcanic hazards to downstream communities because of the fast speeds and the long distances they can travel from their source. Between AD 1600 and

\footnotetext{
* Correspondence: adiefenbach@usgs.gov

${ }^{1}$ U.S. Geological Survey, Cascades Volcano Observatory, 1300 SE Cardinal

Court, Bldg 10, Suite 100, Vancouver, WA 98683, USA

Full list of author information is available at the end of the article
}

2010, lahars triggered during volcanic eruptions killed 37,451 people worldwide, including 23,080 in the 1985 Nevado del Ruiz disaster alone (Witham 2005; Auker et al. 2013). Although typically triggered during or shortly after volcanic eruptions, lahars can also be initiated by noneruptive events, such as heavy precipitation, earthquakes, and gravitational failure, making it difficult to forecast their occurrence (Pierson 1989; Scott et al. 2001). Regardless of how they have formed, recent lahars have caused major economic and business interruption losses, destruction of property and infrastructure, and tragic loss of life (Tayag and Punongbayan 1994; Voight 1996; Scott et al. 2005). 
Throughout the world, various approaches to reduce societal risks associated with lahar hazards have been implemented in communities downstream of volcanoes (see Pierson et al. 2014 for a review). Because preparedness and mitigation resources are not limitless, societal vulnerability assessments are increasingly being used as tools for targeting and prioritizing risk-reduction resources (Birkmann 2006). A clear understanding of how a system is specifically vulnerable to a hazard (typically described in terms of exposure, sensitivity, and adaptive capacity) can help emergency managers and local officials identify opportunities for preparing at-risk communities and mitigating potential losses (Wood 2009; Wood 2011). Knowledge of the number, characteristics, and distribution of people exposed to a hazard provides insight on where potential losses could be the greatest, where potential challenges may exist in responding to and recovering from hazardous events, and the underlying factors that create and amplify societal vulnerability to hazards (National Research Council 2012). In addition, individuals that understand the potential impacts of a hazard in their community and how they are specifically vulnerable are more likely to be involved in planning efforts and pro-active in preparedness strategies (Paton et al. 2001; National Research Council 2012).

Research related to societal vulnerability to volcano hazards has focused on various aspects, such as exposure metrics of people and infrastructure (Rapicetta and Zanon 2009; Wood and Soulard 2009a, b; Kunzler et al. 2012), community resilience (Paton et al. 2001; Tobin and Whiteford 2002), individual risk perceptions (Lavigne et al. 2008; Johannesdottir and Gisladottir 2010), and community preparedness (Gregg et al. 2004). Vulnerability has been assessed using different methods, ranging from geospatial overlays of hazards and assets (Aceves-Quesada et al. 2007) to probabilistic loss assessments (Spence et al. 2005), and from municipal (Kaye et al. 2009) to global (Chester et al. 2000) scales.

Although past vulnerability assessments provide valuable insight to public officials and emergency managers, they have typically focused on individual volcanoes. However, in many parts of the world, emergency managers must contend with and plan for multiple volcanoes in their jurisdictions. Lahar mitigation-decisions then become a difficult process given the multiple sources, the spatial extent of potential threats, the multiple jurisdictions, and the various elements of societal vulnerability (e.g., population, economic, infrastructure, and environmental assets). Therefore, practitioners with resource limitations need methods for determining and prioritizing on which lahar hazards to focus their limited risk-reduction resources. Past efforts to assess societal vulnerability to lahar hazards have neglected to provide managers and policymakers with a characterization of population exposure to lahar hazards across multiple scenarios and among multiple jurisdictions.

The objective of this paper is to present a geospatial approach for characterizing and comparing community exposure to lahar hazards from multiple volcanoes. This process can help emergency managers, elected officials, and the general public to understand the scope of lahar issues across a region and where to potentially prioritize limited risk-reduction resources. To demonstrate this approach, we characterize and compare community variations in population exposure to lahar hazards for five active volcanoes in the State of Washington (USA). We integrate land cover, population, and economic datasets with mapped lahar-hazard zones from Mount Baker, Glacier Peak, Mount Rainier, Mount Adams and Mount St. Helens (Figure 1) to identify the number and distribution of people and businesses that occupy lahar-prone areas. We report on several aspects of population exposure to lahar hazards including (1) the distributions of populations within communities that occupy lahar-prone areas, (2) variations in overall community exposure, and (3) population growth trends in lahar-prone areas over time. Results of this study provide useful information to emergency managers, local officials, and the general public that will help them reduce risk and increase community resilience to volcano hazards.

\section{Washington volcanism}

Washington State is home to five active stratovolcanoesMount Baker, Glacier Peak, Mount Rainier, Mount Adams, and Mount St. Helens-which form the northernmost section of the Cascade volcanic range in the United States (Figure 1). These volcanoes are the most active volcanoes in the Cascade Range, producing more than 90 eruptive episodes over the past 10,000 years (Siebert et al. 2010). With the exception of Mount Adams, all have erupted in historical time, including the welldocumented eruptions of Mount St. Helens in 1980-1986 and 2004-2008.

On average, lahars are the most common and farthestreaching type of hazardous flow from eruptions at volcanoes in Washington State, outranking both pyroclastic flows and lava flows in rate of occurrence. These volcanoes collectively have produced more than 300 lahars from eruptive and noneruptive activity in the past 10,000 years (Hyde and Crandell 1978; Beget 1982, 1983; Frank 1983; Pierson 1985; Hoblitt et al. 1987; Scott 1988; Hildreth and Fierstein 1997; Vallance 1999) and they will likely produce more due to their steep slopes, extensive snow and ice cover, and hydrothermally altered summit areas. Geologic evidence suggests lahars from Mount Baker, Glacier Peak, and Mount Rainier have repeatedly reached the Puget Sound Lowland over the past 


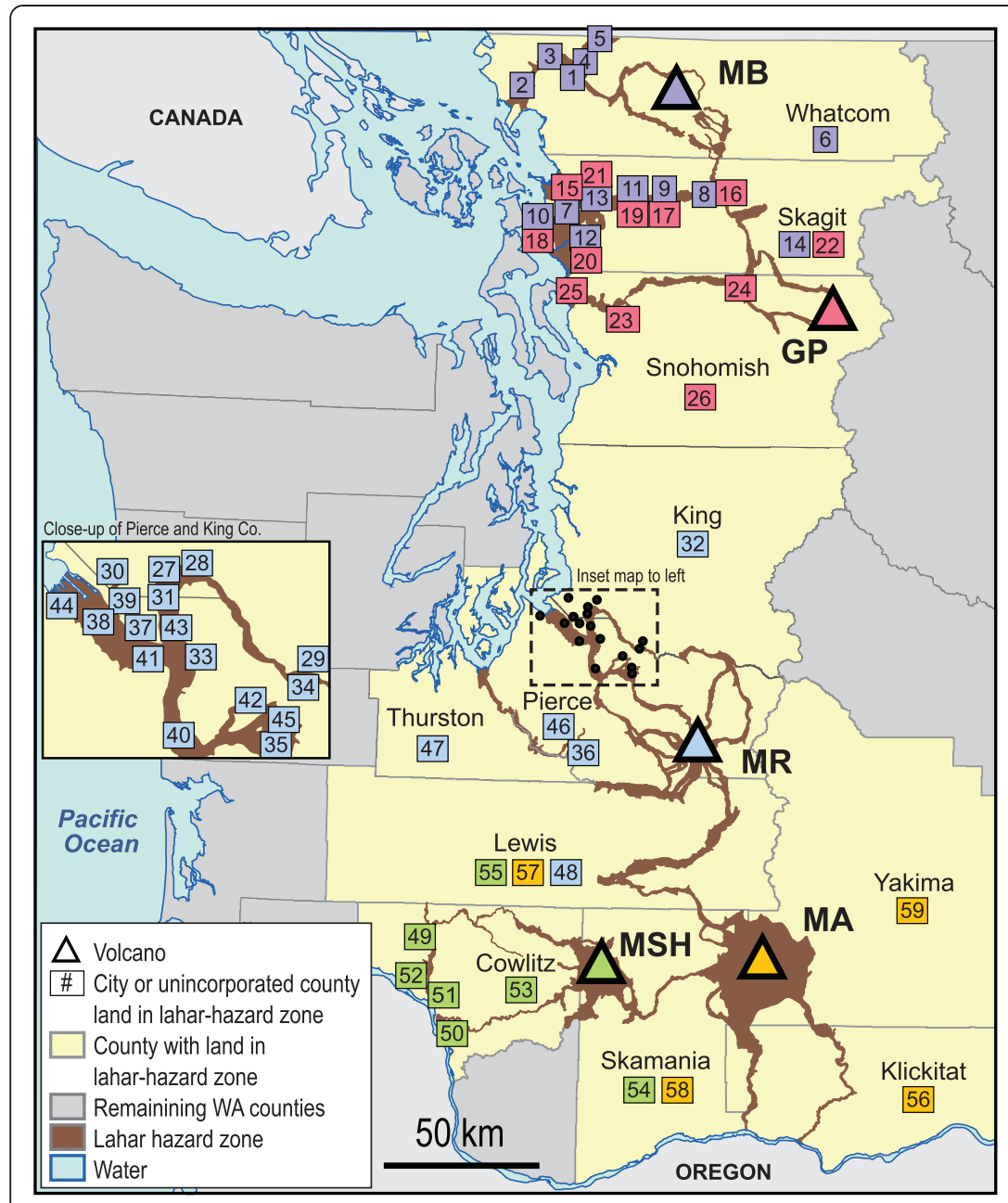

\begin{tabular}{|c|c|}
\hline \multicolumn{2}{|c|}{ Mount Baker (MB) $\square$} \\
\hline 1. Everson & 8. Concrete \\
\hline 2. Ferndale & 9. Hamilton \\
\hline 3. Lynden & 10. La Conner \\
\hline 4. Nooksack & 11. Lyman \\
\hline 5. Sumas & 12. Mount Vernon \\
\hline 6. Unincorp. Whatcom Co. & 13. Sedro-Woolley \\
\hline 7. Burlington & 14. Unincorp. Skagit Co. \\
\hline \multicolumn{2}{|c|}{ Glacier Peak (GP) $\square$} \\
\hline 15. Burlington & 21. Sedro-Woolley \\
\hline 16. Concrete & 22. Unincorp. Skagit Co. \\
\hline 17. Hamilton & 23. Arlington \\
\hline 18. La Conner & 24. Darrington \\
\hline 19. Lyman & 25. Stanwood \\
\hline 20. Mount Vernon & 26. Unincorp. Snohomish \\
\hline
\end{tabular}

\section{Mount Rainier (MR)}

27. Algona 38. Fife

28. Auburn 39. Milton

29. Enumclaw 40. Orting

30. Federal Way 41. Puyallup

31. Pacific 42. South Prairie

32. Unincorp. King Co. 43. Sumner

33. Bonney Lake 44. Tacoma

34. Buckley 45. Wilkeson

35. Carbonado 46. Unincorp. Pierce Co.

36. Eatonville 47. Unincorp. Thurston Co.

37. Edgewood 48. Unincorp. Lewis Co.

Mount St. Helens (MSH)

49. Castle Rock 53. Unincorp. Cowlitz Co.

50. Kalama 54. Unincorp. Skamania Co.

51. Kelso

52. Longview

Mount Adams (MA)

56. Unincorp. Klickitat Co. 58. Unincorp. Skamania Co. 57. Unincorp. Lewis Co. 59. Unincorp. Yakima Co.

Figure 1 Map showing counties and incorporated cities within lahar-hazard zones associated with five active volcanoes in Washington.

10,000 years, where today the majority of the state's population and economy are located. Past lahars from all Washington volcanoes have inundated valley bottoms more than $50 \mathrm{~km}$ away from their flanks and in some cases have exceeded $100 \mathrm{~km}$ (Hoblitt et al. 1987).

Recognizing the threat that lahars pose to downstream communities, local, state, and federal government agencies have worked together on several efforts in Washington to prepare downstream communities and mitigate potential impacts. Volcano monitoring networks have been installed and maintained to detect precursory unrest as early as possible for timely hazard warnings (Guffanti et al. 2010; Ewert et al. 2005). Lahar hazard assessments have been completed that describe the types and extents of hazardous physical processes and to identify areas to focus riskreduction efforts (Gardner et al. 1995; Scott et al. 1995; Wolfe and Pierson 1995; Waitt et al. 1995; Hoblitt et al. 1998). Interagency coordination plans have been developed to support efficient emergency response by local, state, and federal agencies (Washington Military Department and Emergency Management 1999, Washington Military Department, Emergency Management Division 2012). Educational products have been published and disseminated to promote awareness and preparedness (Mastin and Waitt 2000; Scott et al. 2000; Driedger and Scott 2008; Dzurisin et al. 2008, 2013).

Although much work has gone into overall volcano hazard awareness and monitoring both here in Washington and across the United States, less has been done to characterize societal vulnerability to these hazards, specifically the potential impacts to people (Aster et al. 2007; National Research Council 2012). There have been some attempts to examine resident perceptions of volcano threats, such as efforts at Mount St. Helens back in 1980 when the volcano first began to show activity (Perry et al. 1982) and more recent explorations of risk perception from Mount Rainier hazards (Davis et al. 2006; Johnston et al. 2006). Wood and Soulard (2009a, b) were the first studies to assess population exposure to lahar hazards in Washington but focused exclusively on Mount Rainier. 


\section{Study area}

This study of population exposure to lahar hazards in Washington focuses on 11 counties and 36 incorporated cities within them that intersect lahar-hazard zones associated with Mount Baker, Glacier Peak, Mount Rainier, Mount Adams, and Mount St. Helens (Figure 1). Three counties and seven communities are in lahar-hazard zones for multiple volcanoes. There are also 49 unincorporated towns and tribal reservations, as delineated by census-designated-places boundaries (U.S. Census Bureau 2010) that intersect the lahar-hazard zones; however, because emergency services and land-use planning for these towns are performed by county offices, results related to the unincorporated areas within a county are reported at the county level.

The lahar-hazard zones shown in Figure 1 identify areas that could be affected by lahars generated in various river valleys that drain each volcano and are not meant to imply that all delineated areas would be affected by a single event. Each lahar-hazard zone is based on the extents of the maximum known or envisioned flows that have occurred at each volcano and therefore represent the most distal flow hazard zones. The known extent and distribution of lahar deposits from past events serve as a useful guide for establishing lahar-hazard boundaries, but a limitation exists when attempting to account for all possible and all likely scales of hazard extents. Therefore, it is important to note that these laharboundaries are not a prediction but serve merely as a guide to possible future extents. Within each of these distal lahar-hazard zones, hazard decreases with increasing distance down valley from each volcano as well as with increasing height above valley floors, and therefore not all areas within each zone are equally at risk. Additionally, the presence of several dammed reservoirs on rivers that drain some of these volcanoes (e.g., Baker Lake and Lake Shannon on Mount Baker; Alder Lake and Riffe Lake on Mount Rainier) may reduce the extent of lahar flow if they are drawn down in response to volcanic unrest and have enough storage to contain an eruption-generated lahar. Each lahar-hazard zone used in this study represents a different size event, recurrence interval, and degree of hazard and should be evaluated on an individual basis. Further descriptions of each lahar-hazard zone can be found in following volcano hazard assessments; Gardner et al. 1995 (Mount Baker), Waitt et al. 1995 (Glacier Peak), Hoblitt et al. 1998 (Mount Rainier), Scott et al. 1995 (Mount Adams), and Wolfe and Pierson 1995 (Mount St. Helens) along with the digital data series of mapped boundaries (Schilling 1996; Schilling et al. 2008).

Finally, this study focuses solely on lahar hazards and does not include other acute volcano hazards such as lava flows, pyroclastic density currents, or ballistic fall which primarily affect only areas proximal to volcanoes, where climate factors and land ownership (dominantly federal government) significantly limit the numbers of nearby residents. We also do not include ash fall hazards, which can strongly affect distal areas, but whose precise areas of impact can only be forecast on a day to day basis owing to variations in eruption style and magnitude and in wind directions.

\section{Methods}

Community exposure to lahar-hazard zones at the five Washington volcanoes was assessed by using geographic information system (GIS) software to overlay geospatial data representing lahar-hazard zones, jurisdictional boundaries for incorporated cities and counties, and five indicators of human use (area of developed land and number of residents, employees, public venues, and dependent-care facilities). These variables represent data that U.S. jurisdictions are encouraged to collect as they develop State and local hazard mitigation plans (Federal Emergency Management Agency 2001) to qualify for receiving certain types of hazard mitigation grant funds and other nonemergency disaster assistance under the U.S. Hazard Mitigation Grant Program in accordance with the Disaster Mitigation Act of 2000. National datasets were used to calculate all indicators to enable a systematic way of assessing community exposure over large areas with overlapping jurisdictions. We calculate the area of developed land and the number of individuals and businesses in laharprone areas to show emergency managers where hazard education may be most needed and where, in the absence of evacuations, potential losses could be greatest. We also calculate the percentage of these community assets that are in a lahar-hazard zone to provide insight about the relative impact of losses to an entire community. For example, if community A has 100 businesses in a laharhazard zone that represent 10 percent of the local economy and community B has 30 businesses in the lahar-hazard zone that represents 90 percent, then the relative impact of a future lahar may be greater in community $B$ because it has a higher proportion of its businesses in the hazard zone. Economic recovery may be more challenging in community B, given the dramatic impact to businesses.

Developed land was identified using the 2006 National Land Cover Database (NLCD) (Fry et al. 2011), which is a thematic land cover layer of the conterminous United States produced by automated classification routines of Landsat 7 Enhanced Thematic Mapper Plus (ETM+) and Landsat 5 Thematic Mapper (TM) imagery (30-m grid cells). We assume population exposure increases as the area and percentages of developed land within each lahar-hazard zone increases (Wood 2009). We identified developed land using three 2006 NLCD classes: (1) highintensity developed ( $>80 \%$ impervious surfaces, such as 
heavily built-up commercial and residential environments), (2) medium-intensity developed (50-79\% impervious surfaces, such as single family housing and roads), and (3) low-intensity developed (20-49\% impervious surfaces, such as single-family housing).

Various datasets were assembled to characterize the at-risk population. Resident counts were based on blocklevel population counts compiled for the 1990, 2000, and 2010 U.S. Census (U.S. Census Bureau 2010, 2012). Census data assume a uniform distribution of population within a given block. If a census block was not entirely within a lahar-hazard zone, final population values were adjusted proportionately using the ratio of area within and outside the hazard zone. Employees and businesses were determined using the 2010 Infogroup Employer Database (Infogroup 2010), which is a proprietary database that includes business locations, employee counts, and type based on the North American Industrial Classification System (NAICS; U.S. Census Bureau 2007). We used NAICS codes to classify certain businesses as public venues (e.g., museums, overnight accommodations, and parks or other outdoor venues) and dependentpopulation facilities (e.g., child services, elderly services, medical centers, and K-12 schools). We highlight these two business types because individuals at dependentcare facilities may require evacuation assistance due to limited mobility (Wisner et al. 2004), whereas individuals at public venues (e.g., tourists) may have limited situational awareness of volcano hazards. Our analysis serves as an approximation because we were unable to field verify the locations and attributes of the 8,807 businesses within the lahar-hazard zones of the five volcanoes; however, businesses with a physical address (i.e., not a Post Office box) were cross-referenced with the Homeland Security Infrastructure Program (HSIP) Gold 2011 database to improve the accuracy of our reporting. The amounts and percentages of all variables reported serve only as estimates of population exposure to lahar hazards in Washington State and do not take into account uncertainty in data sources, methods, and the spatial and temporal variability of each indicator.

Two composite indices were developed to compare community exposure to lahars for each of the geographic units that intersect lahar-prone areas for each volcano. Composite indices of the amount and percentage of each community's assets were developed by normalizing values in the five population indicators to the maximum value found within each category. Normalizing data to the maximum value creates a common data range of zero to one for each socioeconomic indicator and provides a simple approach for enabling comparisons among disparate data ranges. These values were added together for each geographic unit resulting in a composite score that ranged from zero to five. Each geographic unit has two composite indices that summarize the number and percentage of community assets in lahar-prone areas. To eliminate weighting bias between indices, a final score was then calculated for each geographic unit by normalizing each composite index to maximum values (range of zero to one for the two indices) and then adding the two indices resulting in a final combined score ranging from zero to two. These indices are unit-less, relative values with no absolute meaning for each community, but are used to compare the overall exposure of each community. Communities with higher scores have relatively higher numbers or percentages of population-related indicators and are therefore considered more vulnerable to future lahars.

\section{Results}

Population exposure among the five volcanoes

The lahar-hazard zones for the five active Washington volcanoes contain $274 \mathrm{~km}^{2}$ of developed land, 191,555 residents, 108,719 employees, 433 public venues, and 354 dependent-care facilities. For each variable, Mount Rainier contains the highest percentage of regional (entire study area) totals in the lahar-hazard zones, ranging from $36 \%$ of the public venues to $54 \%$ of the employees (Figure 2). Mount Baker and Glacier Peak represent $21 \%$ to $30 \%$ of regional totals, respectively. Mount Adams and Mount St. Helens represent the lowest percentages at approximately $0 \%$ to $5 \%$ of regional totals, except for developed land at Mount St. Helens which is $12 \%$ of regional totals.

\section{Population exposure at each of the five volcanoes Mount Baker}

The lahar-hazard zone of Mount Baker intersects eight incorporated cities and two counties (Figure 1) and contains 49,212 residents, 24,341 employees at 2,412 businesses, 132 public venues, and 93 dependent-care

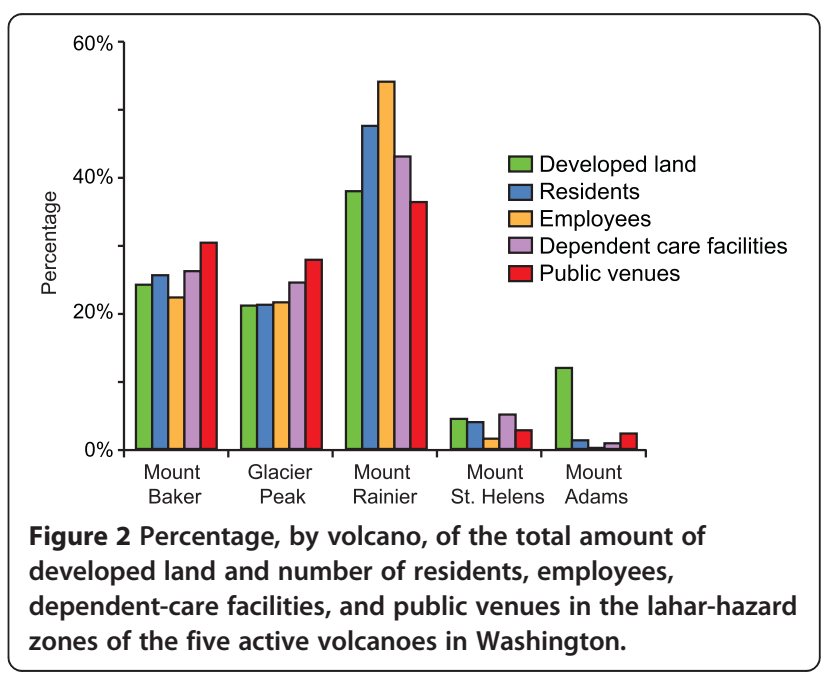


facilities. The majority of these variables are in the unincorporated areas of Skagit and Whatcom counties, followed by the incorporated cities of Burlington, Mount Vernon, and Sedro-Woolley (Figure 3). While these counties and cities have the highest numbers of populations and businesses in hazard zones, other communities have higher percentages of their people and businesses in the zones. For example, Mount Vernon has 5,426 residents in the lahar-hazard zone, but this represents only $17 \%$ of the community; whereas La Conner only has 891 residents in the zone, but they represent $100 \%$ of the community. Other small communities with high percentages of populations in the lahar-hazard zone include Nooksack, Sumas, and Hamilton. The one

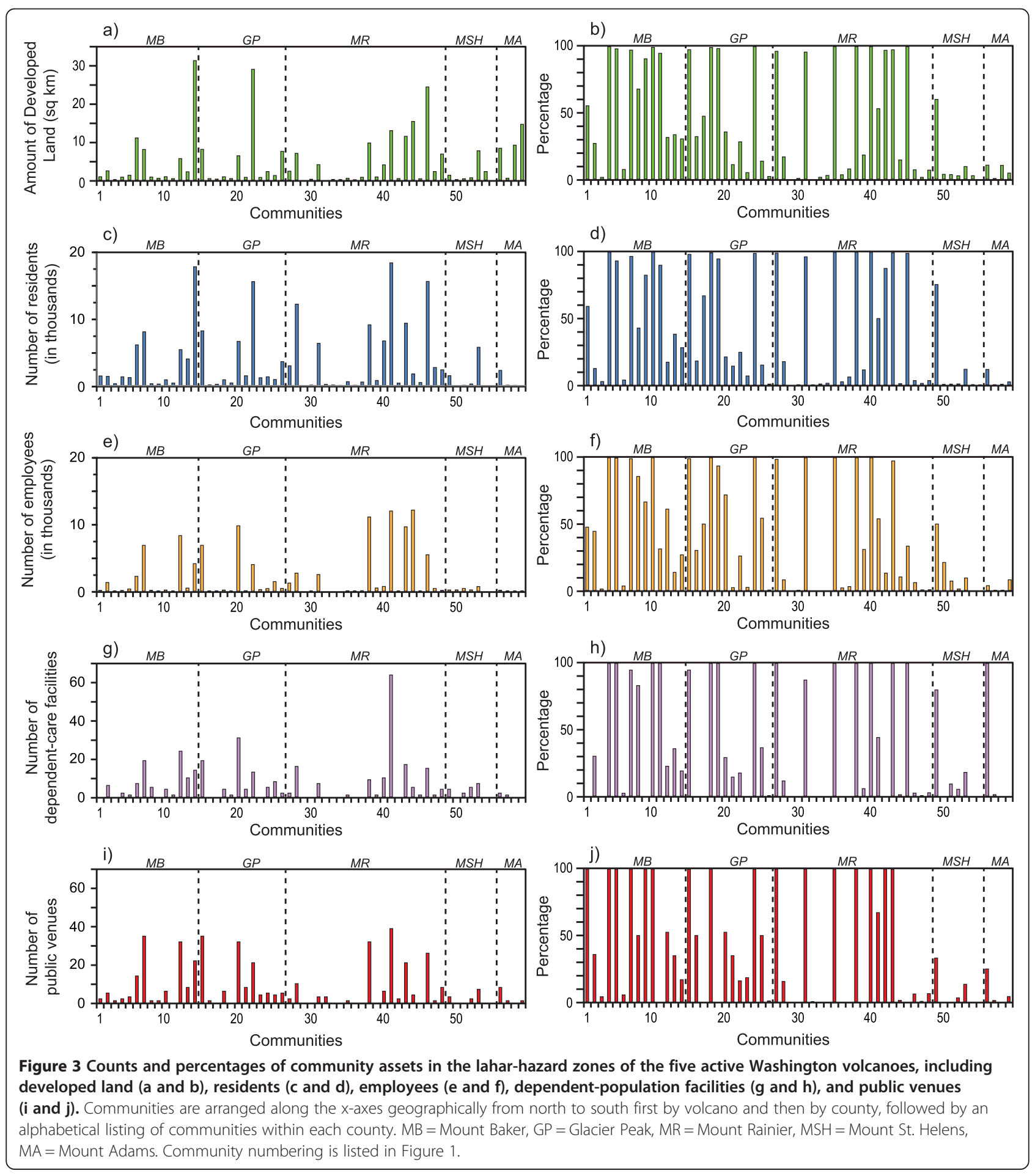


exception to this dichotomy of low numbers versus high percentages is the city of Burlington, which has both high numbers and high percentages. Of the 93 dependent-care facilities that are in the lahar-hazard zone, the majority are schools, adult residential care, child day-care centers, and outpatient-care facilities. The 193 public venues in the lahar-hazard zone include 51 religious venues, 30 overnight accommodations, and 26 parks. Certain public venues in the lahar-hazard zone are high-occupancy tourist sites, such as the Mount Baker Ski Area, the North Cascades National Park, and Mount Baker-Snoqualmie National Forest recreation areas.

\section{Glacier Peak}

The lahar-hazard zone of Glacier Peak intersects five incorporated cities and two counties (Figure 1) and contains 40,819 residents, 23,576 employees at 2,379 businesses, 121 public venues, and 87 dependent-care facilities. The section of the Glacier Peak lahar-hazard zone that follows the Skagit River significantly overlaps the lahar-hazard zone from Mount Baker, resulting in several communities (Burlington, Concrete, Hamilton, La Conner, Lyman, Mount Vernon, and Sedro-Woolley) exposed to lahars originating from both volcanoes. For Glacier Peak lahar-hazard zones, the highest amounts of the developed land, population, and business variables are in the unincorporated areas of Skagit and Snohomish counties and the incorporated cities of Burlington and Mount Vernon (Figure 3). Similar to Mount Baker, some communities contain high numbers of people and businesses in lahar-hazard zones (e.g., Mount Vernon) that represent low percentages of each variable while other communities contain low numbers but high percentages of their populations in hazard zones (e.g., La Conner, Darrington, and Lyman). As was the case with Mount Baker, Burlington is an exception with high numbers and high percentages in the Glacier Peak lahar-hazard zone. The majority of the 87 dependent-care facilities and 121 public venues in the lahar-hazard zone are in Burlington and Mount Vernon.

\section{Mount Rainier}

Among the five Washington volcanoes, the lahar-hazard zone of Mount Rainier (Figure 1) contains the highest number of incorporated cities (18), counties (4), residents $(91,435)$, employees $(58,969$ at 3,821 businesses), public venues (158), and dependent-care facilities (153). Although there are 18 cities and 4 counties with land in the Mount Rainier lahar-hazard zone, the majority of the residents (86\%), employees (75\%), dependent-care facilities (90\%) and public venues (87\%) in the lahar-hazard zone are in cities of Puyallup, Auburn, Sumner, Fife, Orting, and Pacific, and the unincorporated portions of Pierce County (Figure 3). Tacoma is an exception to this list when considering exposed employees given the high number $(12,224)$ and percentage of all employees in the zone (21\%), which represent the concentration of employees near the Port of Tacoma. As was the case with Mount Baker and Glacier Peak, there are many smaller communities (e.g., Algona, Carbonado, South Prairie, and Wilkeson) with lower numbers of exposed populations that represent the majority, if not all in many cases, of the community. There are 151 dependent-care facilities (primarily K-12 schools) in the lahar-hazard zone, with most located in Puyallup. Schools (K-12 grade) are the most abundant and widely distributed type of dependentcare facility identified in the lahar-hazard zone. All of the K-12 schools in six communities (Pacific, Carbonado, Fife, Orting, Sumner, and Wilkeson) are in lahar-hazard zones, representing not only a life-safety issue but a longterm community recovery issue. There are 158 public venues in the lahar-hazard zone (primarily religious organizations, overnight accommodations, and parks), including high-occupancy sites such as casinos, the Puyallup Fairgrounds in Puyallup (over 1 million visitors each September; EventCorp Services 2011), and Mount Rainier National Park (1.7 million visitors in 2010; National Park Service 2011).

\section{Mount St. Helens}

The lahar-hazard zone of Mount St. Helens intersects four incorporated cities and three counties (Figure 1) and contains 7,645 residents, 1,656 employees at 151 businesses, 12 public venues, and 18 dependent-care facilities. The majority of each of these variables is in unincorporated Cowlitz County (Figure 3). Unlike the other volcanoes, the exposed land, populations, and businesses comprise a small percentage of community and county totals. The one exception is the city of Castle Rock, where in-hazard-zone percentages are high and range from $33 \%$ (public venues) to $80 \%$ (dependent-care facilities). Although community totals are relatively low for number of dependent-care facilities in the lahar-hazard zone, often these facilities represent each community's entire facility count, such as schools in Castle Rock and correctional facilities in Kelso. The public venues in the lahar-hazard zone include three parks, four religious venues, four overnight accommodations, and one library. Also in the lahar-hazard zone are access routes and recreational areas of the Mount St. Helens National Volcanic Monument, which draws more than 600,000 visitors to the Johnston Ridge Observatory each year (www.fs.usda.gov; last visited 18 May 2013) and thousands of more visitors on the south and east sides of the monument. 


\section{Mount Adams}

Of the five Washington volcanoes, the lahar-hazard zone of Mount Adams (Figure 1) contains the lowest number of residents $(2,444)$, employees $(177$ at 44 businesses), public venues (10), and dependent-care facilities (3). The lahar-hazard zone crosses four counties (Klickitat, Lewis, Skamania, and Yakima) but no incorporated cities. The majority of the people and businesses are in unincorporated Klickitat County (Figure 3), but percentages are low in each of the four counties. The lahar-hazard zone contains three schools, six overnight accommodations, three religious venues, and one park.

\section{Composite indices of community exposure}

Composite indices describing the amount and the percentage of assets in the lahar-hazard zone for each community and unincorporated area were developed using sums of normalized data in 5 categories-developed land, residents, employees, public venues, and dependent-care facilities. The City of Puyallup (Mount Rainier) has the highest composite amount index (4.4 out of 5), indicating that this community has the highest number of people and businesses in the lahar-hazard zone (Figure 4a). The only geographic area with a higher index in a category was unincorporated Skagit County for the amount of developed land it has in the Mount Baker lahar-hazard zone.

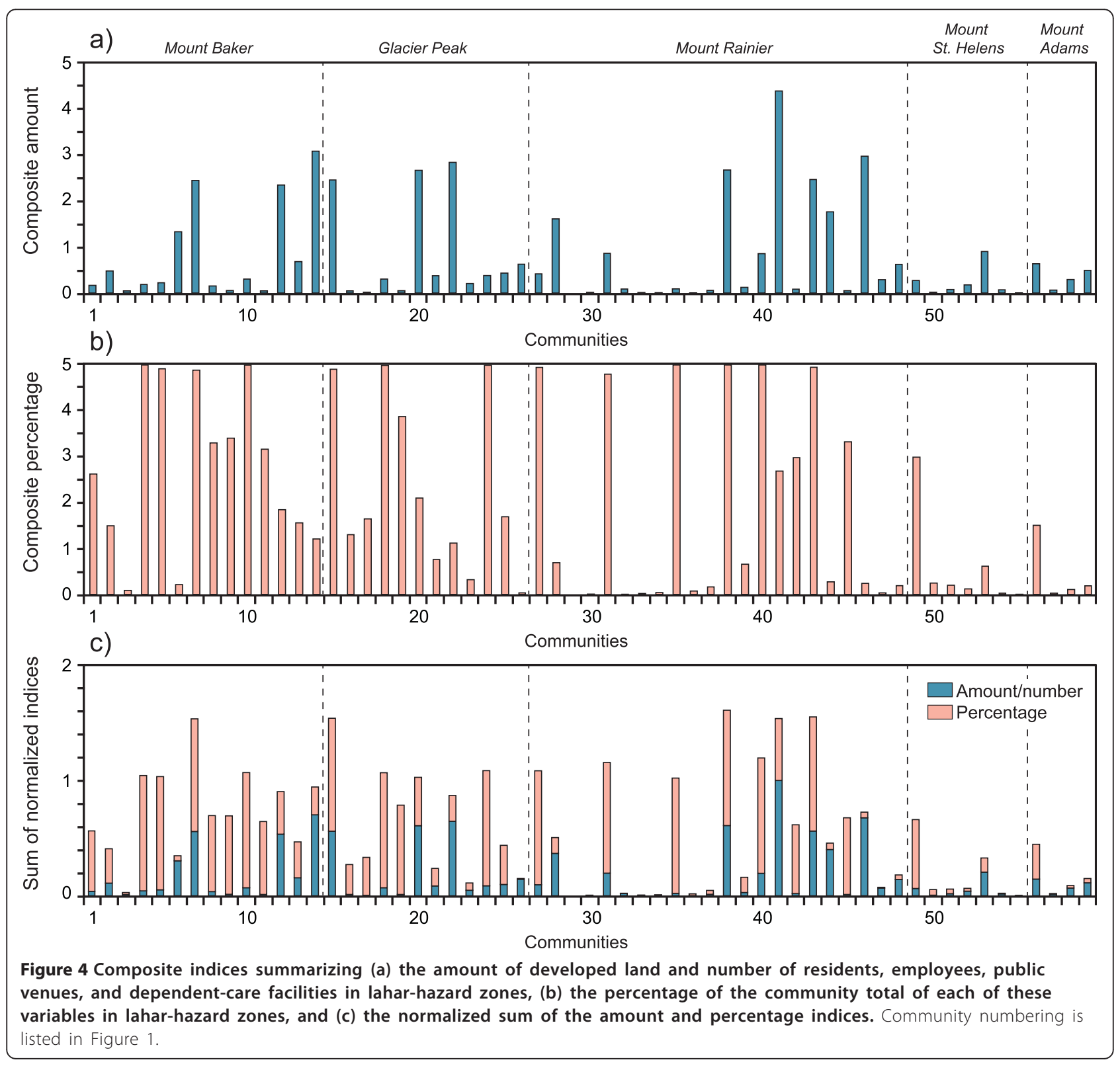


Other communities and counties with high composite amounts include Skagit County (Glacier Peak); Pierce County, Sumner and Fife downstream of Mount Rainier; and Mount Vernon and Burlington for both Glacier Peak and Mount Baker lahar-hazard zones. Tacoma ranks eleventh behind these other communities and counties, due primarily to the highest number of employees in a lahar-hazard zone.

Several communities have composite percentages of 4.8 to 5.0 , indicating that they have the highest percentages of their developed land, populations, and businesses in the lahar-hazard zone for each of the five categories (Figure 4b). In all of these towns, the in-hazard populations and businesses represent close to or exactly $100 \%$ of the community. These types of communities include Darrington, La Conner, and Burlington downstream of Glacier Peak; Nooksack, La Conner, Sumas, and Burlington downstream of Mount Baker; and Fife, Orting, Carbonado, Sumner, Algona, and Pacific downstream of Mount Rainier.

A total of 15 communities have high (1.0 or greater) final composite scores, of which seven are downstream of Mount Rainier, four are downstream of Glacier Peak, and four are downstream of Mount Baker (Figure 4c). Certain communities are in this top tier of exposure due to the magnitude of exposed populations and businesses (e.g., Puyallup), whereas others have high percentages (e.g., Orting and Pacific). The two communities with the highest composite scores (Fife and Sumner) have moderately high amounts (and less than Puyallup) but some of the highest percentages of the various categories.

Clusters of communities with similar exposure to lahar hazards emerge on a plot of amount versus percentage indices for the five variables (Figure 5). The one exception is the city of Puyallup (41) downstream of Mount Rainier, which stands alone. Cluster A includes the city of Mount Vernon and unincorporated Skagit County (both for Glacier Peak and Mount Baker) and Pierce County (Mount Rainier) and represents areas with relatively high amounts but low percentages of the five variables. Cluster B communities (Sumner and Fife at Mount Rainier and Burlington at Glacier Peak and Mount Baker) have similar amounts as those in cluster A, but higher percentage index values (close to or equal to 1.0). Cluster $\mathrm{C}$ communities have similarly high percentage index values, but very low amount index values. Cluster D communities are similar to cluster $C$, but with lower percentage index values. Cluster $\mathrm{E}$ represents the bulk of the communities in the study area, with relatively low amount and percentage index values. Figure 5 also shows how the lower right of the graph (i.e., areas with amount index values greater than their percentage index values) is dominated by the unincorporated portions of the 11 counties.

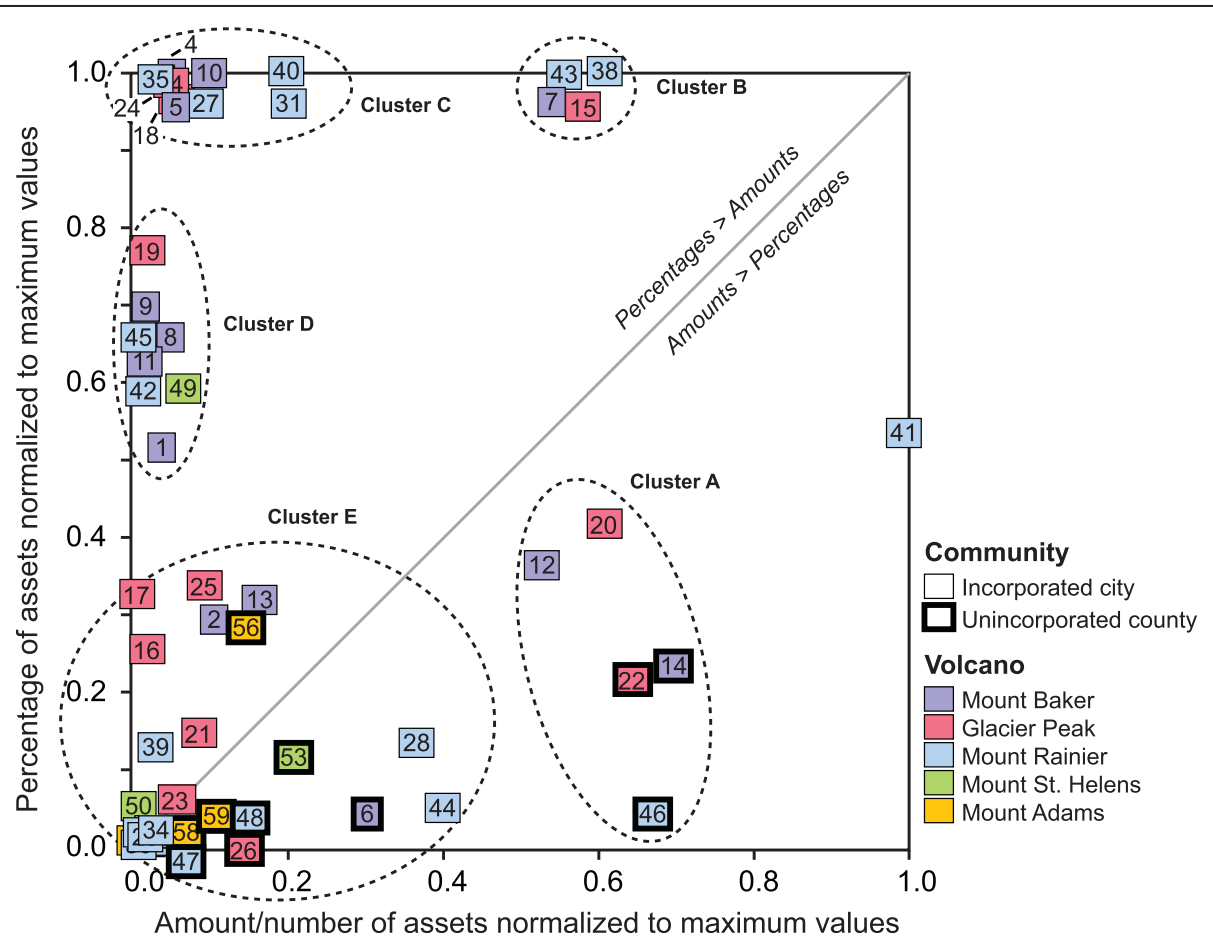

Figure 5 Comparison of normalized amount and percentage indices for communities in the lahar-hazard zones of the five active volcanoes in Washington. Unincorporated county land is identified with heavier outlines. Community numbering is listed in Figure 1. Any community not identified with its own colored square is located near the origin in cluster $E$ and has values of less than 0.04 for both the relative amount and percentage of assets in lahar-hazard zones. 


\section{Changes in community exposure to lahar hazards between 1990 and 2010}

Residential populations within lahar-prone areas of Washington State have increased by 48,080 residents over the 20-year time period between 1990 and 2010 . More than half of this total increase is from population expansion within the Mount Rainier lahar-hazard zone (+24,619 residents), followed by smaller increases at Mount Baker $(+12,003)$, Glacier Peak $(+9,128)$, Mount St. Helens $(+2,067)$, and Mount Adams $(+263)$. At the community level (Figure 6a), the greatest increases in population during this time period were in the Mount Rainier communities of Orting $(+4,595$ residents, representing a $214 \%$ increase) and Fife (+4,436 residents, representing a 94\% increase), as well as Burlington for both Mount Baker and Glacier Peak (+3,900 residents, representing a $90-92 \%$ increase). The number of residents in lahar-hazard zones increased in all communities and counties except for small decreases in Enumclaw, Federal Way, Edgewood, Castle Rock, Kelso, Concrete, and the unincorporated areas of Lewis, Yakima, Snohomish, and King Counties.

Although residential numbers increased through time, the percentage of residents in the lahar-hazard zone across the five Washington volcanoes (Figure 6b) remained the same between 1990 and 2010 (4.4\% and 4.3\%, respectively). Although Orting more than tripled and Fife, Algona, and Burlington nearly doubled their in-hazard-zone population, the communities saw little to no change in the overall percentage of their communities in the lahar-hazard zone. This is because each town was completely within lahar-hazard zones in 1990 and any new growth still resulted in an overall percentage of $100 \%$. Decreases in the community percentage of exposed populations in most of the remaining communities and counties in the study area were not because the in-hazard-zone population decreased but because of much larger increases in residents elsewhere in the community. For the few towns that did have an increase in the community percentage of exposed populations, the increase was relatively small on the order of 1 to $2 \%$.

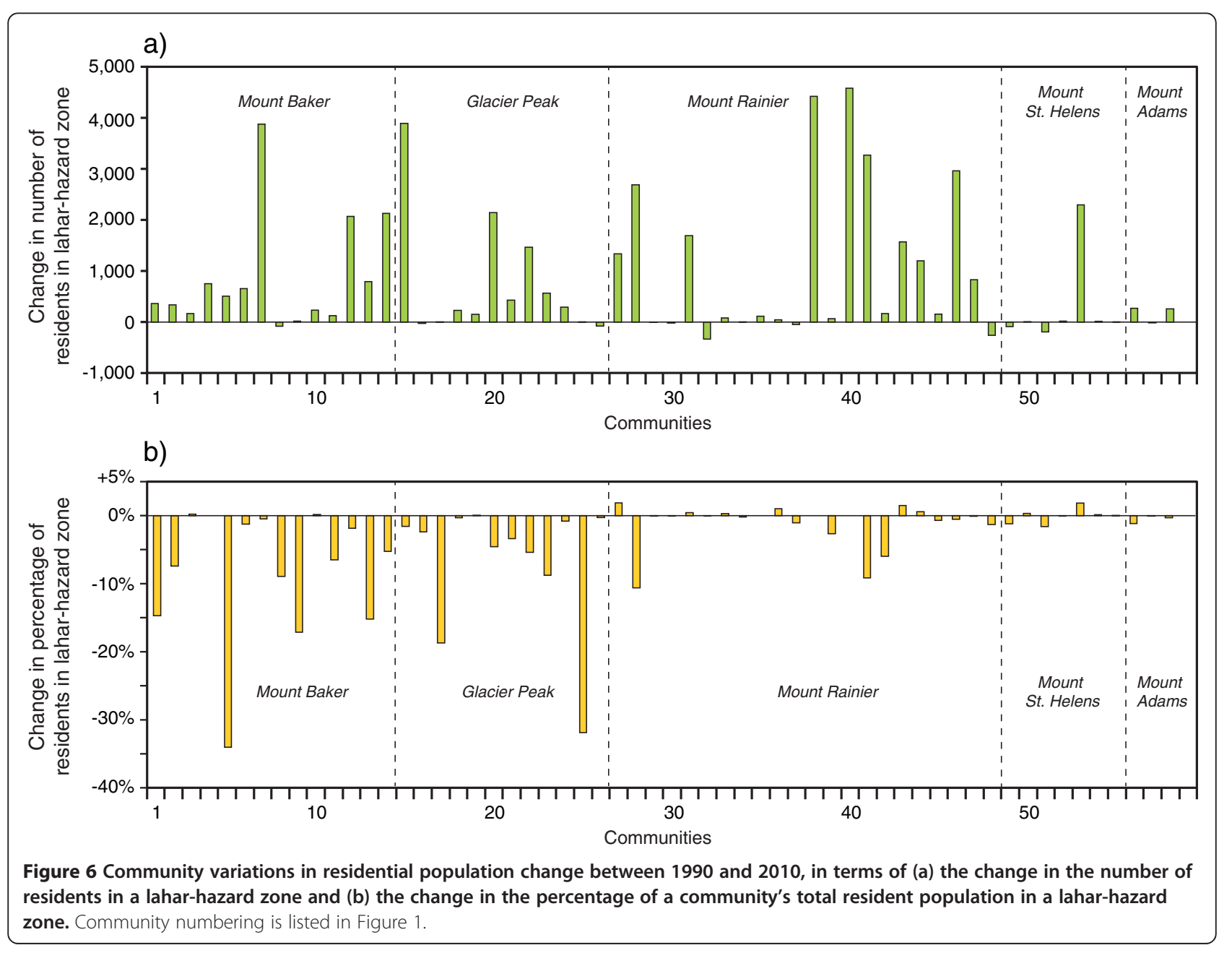




\section{Discussion}

Understanding how communities are vulnerable to lahars is a critical step for elected officials, emergency managers, and the public in their efforts to mitigate potential losses, as well as prepare for, respond to, and recover from future events. Previous efforts to characterize societal vulnerability to lahar hazards have focused largely on threats posed by single volcanoes. Missing from the literature are efforts to characterize and compare variations in community exposure to lahar hazards associated with multiple volcanoes. In the State of Washington, there are five active volcanoes, each having the potential to generate catastrophic lahars that could strike communities tens of kilometers downstream. In this section, we discuss the implications of our results on risk-reduction planning in Washington, as well as for lahar risk-reduction efforts in general throughout the world.

Results suggest that Washington lahar-hazard zones contain an estimated 191,555 residents, 108,719 employees at 8,807 businesses, 433 public venues that attract visitors, and 354 dependent-care facilities that house individuals who will need assistance to evacuate. Population exposure to lahar hazards varies greatly among eleven counties in Washington State. The communities with high numbers of assets tend to be larger in size (e.g., Puyallup, Mount Vernon, and Burlington) and represent high loss potentials. The communities with high percentages tend to be smaller in size (e.g., Nooksack, Orting), where loss of even a small number of assets may represent the entire community. Potential loss of a large number versus a high percentage of assets within communities represents information emergency managers, policymakers, and the general public can use in order to make decisions on where to focus risk reduction efforts if time and resources are limited (Wood and Soulard 2009a).

Community clusters shown in Figure 5 can be used to identify communities with similar vulnerability issues. For example, the community and unincorporated areas of counties in cluster A may experience high losses from future events, but may be able to respond and recover with fewer external resources than other areas because the exposed populations and businesses represent low percentages of each community. Conversely, communities in clusters $\mathrm{B}$ and $\mathrm{C}$ may have a more difficult time recovering from a lahar given that all or the majority of their communities could be affected. Communities within similar clusters may wish to create partnerships to leverage limited risk-reduction resources. For example, although they are threatened by different volcanoes, the communities of cluster B (Sumner and Fife near Mount Rainier and Burlington near Mount Baker and Glacier Peak) have common issues of moderately high numbers of assets that constitute their entire communities. Similarly, a partnership might benefit the small cluster $\mathrm{C}$ communities (e.g., Orting, Pacific, Algona, and Carbonado near Mount Rainier and La Conner and Sumas near Mount Baker), which lie entirely in lahar-hazard zones. Riskreduction successes may be transferred efficiently among communities in a single cluster.

When assessed in a state-wide perspective, Mount Rainier poses the biggest threat to assets in all sectors (Figure 2). The lahar-hazard zones of Mount Baker and Glacier Peak also contain high numbers of assets in each sector, the majority of each are from the same communities located in Skagit County where the lahar-hazard zones from each volcano significantly overlap in extent. The unincorporated areas of several counties are also exposed to multiple lahar-hazard zones (i.e., Glacier Peak and Mount Baker; Mount St. Helens and Mount Adams; Mount Rainier, Mount St. Helens and Mount Adams). Such cases present an educational outreach opportunity to raise awareness in communities about hazards related to multiple volcanoes.

The distribution and number of residential populations within each lahar-hazard zone may also warrant targeted education and preparedness efforts. The fact that significant portions of the residential population within the lahar-hazard zones of Mount Baker (49\%), Glacier Peak (47\%), Mount St. Helens (76\%) and Mount Adams (100\%) reside in the unincorporated county areas (Figure 3) identifies a need for education outreach, awareness programs and evacuation planning for rural residents outside established community boundaries. In contrast, only $20 \%$ of residents in the lahar-hazard zone at Mount Rainier do not live in incorporated communities, indicating that community based awareness programs will likely reach a significant percent of the at-risk population.

Within each individual study area there are significant differences among communities in the types of population within lahar-prone areas (Figure 3). For example, within the Mount Baker lahar-hazard zone, the communities of Burlington and Mount Vernon and the unincorporated areas of Skagit County have high numbers of many types of people, whereas the exposed populations in other communities are dominated by certain types of populations, such as residents (e.g., Auburn and Orting) or employees (e.g., Tacoma and Stanwood). Education efforts will need to be tailored to each audience's needs in order to be most effective. For residents, sustained educational efforts that capitalize on existing social networks (e.g., city councils, neighborhood groups, schools, and parent and teacher associations) may be most effective (Wood and Soulard 2009a, b). Employees at businesses with large customer bases would ideally be trained in evacuation procedures; however, employees who reside in areas outside of lahar-hazard zones may be unaware 
of attendant hazards and will require access to educational materials (Wood and Soulard 2009a, b). Additional evacuation planning and staff training may be required in communities with high numbers of dependent-care facilities (e.g., Puyallup, Mount Vernon, and Burlington). The number and distribution of these various population groups provides essential information to officials when formulating risk-reduction strategies.

Residents and employees represent the dominant type of individuals within each hazard zone; however, because public venues and dependent-facilities do not include population counts at each facility it is difficult to compare actual population numbers between the five different indicator categories. The number and type of public venues and businesses in the lahar-prone areas of each community provides some insight about tourist populations but does not fully capture the range and magnitudes of tourist populations that may be exposed to lahar-hazards. An estimation of visitor statistics to areas near each volcano for recreation and tourism provides a first order assessment of transient populations within hazard prone areas but further research is warranted to better understand the number, distribution, demographics, and occupancy times to prepare and disseminate effective education and awareness information for these populations. Examples of targeted education outreach toward visitors and outdoor recreationists can be found at the visitor centers and on trailheads at Mount Rainier National Park and the Mount St. Helens National Volcanic Monument.

Examining changes in population exposure over time in lahar-prone areas provides insight on where new education efforts may be needed. Lahar education and evacuation training are long-term investments of time and resources and will not be one-time efforts. In Washington State, the number of people at risk from lahars continues to increase as residential populations, economic development, and recreation activities around these volcanoes increase. This is evident in some communities that have doubled (e.g., Burlington, Algona, and Fife) and tripled (Orting) their at-risk population in the last 20 years. Given the lack of lahar-hazard disclosure in property transactions, many of these new residents may be unaware of the lahar threat. In addition to increases in residential exposure, some of these communities (e.g., Burlington and Fife) also have relatively high numbers of public venues in their hazard zones, indicating the possibility of even more exposed populations.

Finally, although methods described in this paper provide insight on variations in population exposure to lahar hazards, they should not be construed as loss estimates. Results only summarize the spatial coincidence of populations and proxies for populations (e.g., public venues) with lahar-hazard zones. Unlike earthquakes that strike instantly and with little to no warning, lahars provide some level of warning due to instrumented warning systems, volcano monitoring networks that detect when a volcano is reawakening and moving toward eruption or hazard alerts spread through multiple channels of communication. With such warnings and a population aware of how to respond, people should be out of harm's way before a lahar reaches their communities. Beyond the immediate risk associated with lahar inundation, a significant problem for many communities will be managing displaced populations and dealing with long recovery time frames (years to decades) of damaged communities. To fully understand the threat that lahars pose to these communities, this exposure analysis will hopefully serve as a foundation for complementary studies designed to understand the perceptions, preparedness levels, likely behavior during an event, and general adaptive capacity of at-risk individuals. To date, there has been little work to gauge the perceptions and preparedness of at-risk individuals in this region. A series of surveys conducted in 2006 in Orting and Puyallup suggested that awareness of Mount Rainier lahar-hazards was high but that little had been done at the household level to prepare for future events (Davis et al. 2006; Johnston et al. 2006). Also lacking in this region are evacuation studies (e.g., Wood and Schmidtlein 2013) to determine whether or not individuals would have sufficient time to successfully evacuate out of lahar-hazard zones.

\section{Conclusion}

This study provides a first-order assessment of population exposure to lahar-hazards in Washington State and is intended to further the dialogue on understanding societal risk in the region. Population-exposure analysis from multiple volcanoes and across multiple jurisdictions helps emergency managers understand and communicate where potential loss of life may be concentrated and where to focus risk-reduction efforts. Results presented here illustrate that although lahars are regional hazards that will impact communities in different ways, there are many commonalities in community exposure across multiple volcanoes. These results support the notion that a place-based context is important for understanding community vulnerability to volcano hazards (Jones and Andrey 2007). A more regional comparative approach to assessing and addressing vulnerability to lahar-hazards is warranted, as opposed to one-size-fits-all mitigation and preparedness strategies that inadequately address differences in community context. Communities with common issues of vulnerability to lahar-hazards may wish to build partnerships to leverage limited resources, especially communities downstream of different volcanoes that may have not previously engaged in collaborative discussions. Data 
presented here will be used by emergency managers and local officials to help identify and tailor future preparedness, mitigation, recovery planning, and outreach activities within specific communities in Washington State. Although this study provides only a snapshot in time of community exposure to lahar-hazards in the State of Washington, its broad geographic coverage provides a regional scope that will allow emergency managers to identify hot-spot areas for more refined investigations related to adaptive capacity and resilience. In addition, as future data releases (e.g., decadal population counts) occur, additional research into how these systems change over time are warranted and could provide an on-going blueprint for risk-reduction planning across the region.

\section{Competing interests}

The authors declare that they have no competing interests.

\section{Authors' contributions}

AKD participated in the study's design, compiled various datasets, carried out data analyses, and drafted the manuscript. NJW conceived of the study, carried out analyses, produced figures, and drafted the manuscript. JWE participated in the study's design. All authors read and approved the final manuscript.

\section{Acknowledgements}

This study was a cooperative effort between the U.S. Geological Survey (USGS) Volcano Science Center and USGS Land Change Science Program. Special thanks to John Schelling (Washington State Military Department Emergency Management Division) and Mara Tongue (USGS) who provided support for this study and Jamie Ratliff (USGS) who provided the compiled 2010 Census data. We thank Jeff Peters and two anonymous reviewers for their helpful comments. Any use of trade names is for descriptive purposes only and does not imply endorsement by the U.S. Government.

\section{Author details}

'U.S. Geological Survey, Cascades Volcano Observatory, 1300 SE Cardinal Court, Bldg 10, Suite 100, Vancouver, WA 98683, USA. ${ }^{2}$ U.S. Geological Survey Western Geographic Science Center, 2130 SW 5th Ave., Portland, OR 97201, USA.

Received: 24 October 2014 Accepted: 14 January 2015

Published online: 01 February 2015

\section{References}

Aceves-Quesada JF, Diaz-Salgado J, Lopez-Blanco J (2007) Vulnerability assessment in a volcanic risk evaluation in Central Mexico through a multi-criteria-GIS approach. Nat Hazards 40:339-356

Aster R, Bergantz G, Carn S, Serafino G, Wilson J, Yepes H, White K (2007) Review of the United States Geological Survey Volcano Hazards Program. Report of the American Association for the Advancement of Science Research Competitiveness Program, 35 p. [http://volcanoes.usgs.gov/publications/pdf/ aaas2007.pdf

Auker MR, Sparks RSJ, Siebert L, Crosweller HS, Ewert J (2013) A statistical analysis of the global historical volcanic fatalities record. J Appl Volcanol 2(2):24

Beget JE (1982) Postglacial volcanic deposits at Glacier Peak, Washington, and potential hazards from future eruptions, U.S. Geological Survey Open-File Report. pp 82-830

Beget JE (1983) Glacier Peak, Washington: a potentially hazardous Cascade volcano. Environ Geol 5:83-92

Birkmann J (2006) Measuring vulnerability to promote disaster-resilience societies: conceptual framework and definitions. In: Birkmann J (ed) Measuring vulnerability to natural hazards: towards disaster resilience societies. United Nations University Press, Tokyo, pp 9-54

Chester DK, Degg M, Duncan AM, Guest JE (2000) The increasing exposure of cities to the effects of volcanic eruptions: a global survey. Global Environmental Change Part B: Environ Haz 2(3):89-103
Davis M, Johnston D, Becker J, Leonard G, Coomer M, Gregg C (2006) Risk perceptions and preparedness: Mt Rainier 2006 community assessment tabulated results. GNS Science Report 2006/17, Institute of Geological and Nuclear Sciences Limited. p 43

Driedger C, Scott W (2008) Mount Rainier - living safely with a volcano in your backyard, U.S. Geological Survey Fact Sheet. pp 2008-3062

Dzurisin D, Stauffer PH, Hendley JW II (2008) Living with volcanic risk in the Cascades, U.S. Geological Survey Fact Sheet. pp 165-197, (1.1) [http://pubs.usgs.gov/fs/1997/fs165-97/]

Dzurisin D, Driedger CL, Faust LM (2013) Mount St. Helens, 1980 to now - what's going on? U.S. Geological Survey Fact Sheet. pp 2013-3014, (1.1) [http://pubs.usgs.gov/fs/2013/3014/]

EventCorp Services (2011) Washington State Fair: attendance and demographics. http://www.thefair.com/sponsorship/attendance-demographics/. Accessed 01 Sept 2013

Ewert JW, Guffanti M, Murray TL (2005) An assessment of volcanic threat and monitoring capabilities in the United States: framework for a National Volcano Early Warning System NVEWS. U.S. Geological Survey Open-File Report 2005-1164

Federal Emergency Management Agency (2001) State and local mitigation planning how-to-guide No. 2 - understanding your risks. FEMA 386-2 [http://www.fema.gov/library/viewRecord.do?id=1880]

Frank D (1983) Origin, distribution, and rapid removal of hydrothermally formed clay at Mount Baker, Washington, U.S. Geological Survey Professional Paper 1022-E. p 31

Fry J, Xian G, Jin S, Dewitz J, Homer C, Yang L, Barnes C, Herold N, Wickham J (2011) Completion of the 2006 National land cover database for the conterminous United States. Photogramm Engin Rem S 77(9):858-864

Gardner CA, Scott KM, Miller CD, Myers B, Hildreth W, Pringle PT (1995) Potential volcanic hazards from future activity of Mount Baker, Washington, U.S. Geological Survey Open-File Report. pp 95-498

Gregg CE, Houghton BF, Paton D, Swanson DA, Johnston DM (2004) Community preparedness for lava flows from Mauna Loa and Hualalai volcanoes, Kona, Hawaii. Bull Volcanol 66:531-540

Guffanti M, Diefenbach AK, Ewert JW, Ramsey DW, Cervelli PF, Schilling SP (2010) Volcano-monitoring instrumentation in the United States, 2008. U.S. Geological Survey Open-File Report 2009-1165

Hildreth W, Fierstein J (1997) Recent eruptions of Mount Adams, Washington Cascades, USA. Bull Volcanol 58:472-490

Hoblitt RP, Miller CD, Scott WE (1987) Volcanic hazards with regard to siting nuclear-power plants in the Pacific Northwest, U.S. Geological Survey Open-File Report. pp 87-297

Hoblitt R, Walder J, Driedger C, Scott K, Pringle P, Vallance J (1998) Volcano hazards from Mount Rainier, Washington, revised 1998, U.S. Geological Survey Open-File Report. pp 98-428

Hyde JH, Crandell DR (1978) Postglacial deposits at Mount Baker, Washington, and potential hazards from future eruptions, U.S. Geological Survey Professional Paper 1022-C

InfoGroup (2010) Employer database: online dataset [http://referenceusagov.com/ Static/Home, last accessed Oct 10, 2014]

Johannesdottir G, Gisladottir G (2010) People living under threat of volcanic hazard in southern Iceland: vulnerability and risk perception. Nat Hazard Earth Sys 10(2):407-420

Johnston D, Becker J, Coomer M, Ronan K, Davis M, Gregg C (2006) Children's Risk Perceptions and Preparedness: Mt Rainier 2006 Hazard Education Assessment Tabulated Results. GNS Science Report 2006/16, Institute of Geological and Nuclear Sciences Limited. p 30

Jones B, Andrey J (2007) Vulnerability index construction: methodological choices and their influences on identifying vulnerable neighborhoods. Int J Emerg Manag 4(2):269-295

Kaye G, Cole J, King A, Johnston D (2009) Comparison of risk from pyroclastic density current hazards to critical infrastructure in Mammoth Lakes, California, USA, from a new Inyo craters rhyolite dike eruption versus a dacitic dome eruption on Mammoth Mountain. Nat Hazards 49(3):541-563

Kunzler M, Huggel C, Ramirez JM (2012) A risk analysis for floods and lahars: case study in the Cordillera Central of Colombia. Nat Hazards 64(1):767-796

Lavigne F, De Coster B, Juvin N, Flohic F, Gaillard J, Texier P, Mornin J, Sartohadi J (2008) People's behavior in the face of volcanic hazards: perspectives from Javanese communities, Indonesia. J Volcanol Geotherm Res 172:273-287

Mastin L, Waitt R (2000) Glacier Peak - history and hazards of a Cascade volcano, U.S. Geological Survey Fact Sheet 058-00 
National Park Service (2011) Mount Rainier annual visitor statistics 1967-2010. http://www.nps.gov/mora/parkmgmt/upload/vis-stats-1967-2010-2.pdf. Accessed 08 Jan 2011

National Research Council (2012) Disaster Resilience: A National Imperative. The National Academies Press, Washington, DC, p 244

Paton D, Millar M, Johnston D (2001) Community resilience to volcanic hazard consquences. Nat Hazards 24:157-169

Perry R, Lindell M, Greene M (1982) Threat perception and public response to volcano hazard. J Soc Psychol 116:199-204

Pierson TC (1985) Initiation and flow behavior of the 1980 Pine Creek and Muddy River lahars, Mount St. Helens, Washington. Bull Geol Soc Am 96:1056-1069

Pierson TC (1989) Hazardous hydrologic consquences of volcanic eruptions and goals for mitigative action: an overview. In: Starosolsky O, Melder OM (eds) Hydrology of disasters, Proc of the Technical Conference in Geneva, WMO, James and James, London (1989). pp 220-236

Pierson TC, Wood N, Driedger C (2014) Reducing risk from lahar hazards_concepts, case studies, and roles for scientists. J Appl Volcanol 3(16):25

Rapicetta S, Zanon V (2009) GIS-based method for the environmental vulnerability assessment to volcanic ashfall at Etna Volcano. Geolnformatica 13(3):267-276

Schilling SP (1996) Digital Data Set of Volcano Hazards for Active Cascade Volcanoes, Washington, U.S. Geological Survey Open-File Report. pp 96-178

Schilling S, Doelger S, Hoblitt R, Walder J, Driedger C, Scott K, Pringle P, Vallance J (2008) Digital data for volcano hazards from Mount Rainier, Washington. U.S. Geological Survey Open-File Report 2007- 1220

Scott KM (1988) Origins, Behavior, and Sedimentology of Lahars and Lahar-runout Flows in the Toutle-Cowlitz River System, Mount St. Helens, Washington, U.S. Geological Survey Professional Paper 1447-A

Scott WE, Iverson RM, Vallance JW, Hildreth W (1995) Volcano Hazards in the Mount Adams region, Washington, U.S. Geological Survey Open-File Report. pp 95-492

Scott KM, Hildreth W, Gardner CA (2000) Mount Baker - Living with an Active Volcano, U.S. Geological Survey Fact Sheet 059-00

Scott KM, Luis Macias J, Naranjo JA, Rodriguez S, McGeehin JP (2001) Catastrophic debris flows transformed from landslides in volcanic terrains: mobility, hazard assessment, and mitigation strategies, U.S. Geological Survey Professional Paper. p 1630

Scott KM, Vallance JW, Kerle N, Luis Macias J, Strauch W, Devoli G (2005) Catastrophic precipitation-triggered lahar at Casita volcano, Nicaragua: occurrence, bulking and transformation. Earth Surf Proc Land 30(1):59-79

Siebert L, Simkin T, Kimberly P (2010) Volcanoes of the World, 3rd edn. University of California Press, Berkeley

Spence RJS, Kelman I, Calogero E, Toyos G, Baxter PJ, Komorowski JC (2005) Modelling expected physical impacts and human casualties from explosive volcanic eruptions. Nat Hazards Earth Sys 5(6):1003-1015

Tayag JC, Punongbayan RS (1994) Volcanic disaster mitigation in the Philippines: experience from Mt. Pinatubo. Disasters 18(1):1-15

Tobin GA, Whiteford LM (2002) Community resilience and volcano hazards: the eruption of Tungurahua and evacuation of the Faldas in Ecuador. Disasters 25(1):28-48

U.S. Census Bureau (2007) North American Industry Classification System. U.S. Census Bureau. http://www.census.gov/epcd/www/naics.html. Accessed 01 April 2010

U.S. Census Bureau (2010) 2010 TIGER/Line ${ }^{\circledast}$ Shapefiles: U.S. Census Bureau. http://www.census.gov/cgi-bin/geo/shapefiles2010/main. Accessed 26 January 2012

U.S. Census Bureau (2012) American FactFinder: U.S. Census Bureau. http://factfinder2.census.gov/faces/nav/jsf/pages/index.xhtml. Accessed 03 June 2012

Vallance (1999) Postglacial Lahars and Potential Hazards in the White Salmon River System on the Southwest Flank of Mount Adams, Washington, U.S. Geological Survey Bulletin 2161. p 49

Voight B (1996) The management of volcano emergencies: Nevado del Ruiz. In: Scarpa R, Tilling Rl (eds) Monitoring and Mitigation of Volcano Hazards. Springer, Berlin, Heidelberg, pp 719-769

Waitt RB, Mastin LG, Beget JE (1995) Volcanic-hazard Zonation for Glacier Peak Volcano, Washington, U.S. Geological Survey Open-File Report. pp 95-499

Washington Military Department, Emergency Management Division (1999) Mount Rainier Volcanic Hazards Response Plan, WMD-EMD Volcano Coordination Plan. p 86

Washington Military Department, Emergency Management Division (2012) Mount Baker/Glacier Peak coordination plan: coordinating efforts between governmental agencies in the event of volcanic unrest at Mount Baker or Glacier Peak, Washington, WMD-EMD Volcano Coordination Plan. p 39

Wisner B, Blaikie P, Cannon T, Davis I (2004) At risk - Natural Hazards, People's Vulnerability and Disasters, 2nd edn. Routledge, New York, p 471

Witham C (2005) Volcanic disasters and incidents - a new database. J Volcanol Geotherm Res 148:191-233

Wolfe EW, Pierson TC (1995) Volcanic-Hazard Zonation for Mount St. Helens, Washington, U.S. Geological Open-File Report. pp 95-497

Wood N (2009) Tsunami exposure and estimation with land-cover data - Oregon and the Cascadia subduction zone. Appl Geog 29:158-170

Wood N (2011) Understanding risk and resilience to natural hazards. U.S. Geological Survey Fact Sheet 2011-3008 [http://pubs.usgs.gov/fs/2011/3008/]

Wood NJ, Schmidtlein M (2013) Community variations in population exposure to near-field tsunami hazards as a function of pedestrian travel time to safety. Nat Hazards 65(3):1603-1628

Wood NJ, Soulard CE (2009a) Community exposure to lahar hazards from Mount Rainier, Washington. U.S. Geological Survey Scientific Investigations Report 2009-5211

Wood NJ, Soulard CE (2009b) Variations in population exposure and sensitivity to lahar hazards from Mount Rainier, Washington. J Volcanol Geotherm Res 188:367-378

\section{Submit your manuscript to a SpringerOpen ${ }^{\circ}$ journal and benefit from:}

- Convenient online submission

Rigorous peer review

- Immediate publication on acceptance

- Open access: articles freely available online

- High visibility within the field

- Retaining the copyright to your article

Submit your next manuscript at springeropen.com 